Tropical Agricultural Pesearch \& Extension 18 (2): 2015

\title{
IN VITRO SHOOT PROLIFERATION OF ROSEWOOD (Dalbergia latifolia: Fabaceae): A POTENT HIGH QUALITY TIMBER SPECIES
}

Subasinghe S*, Warakagoda PS and Abeywickrama WHT

Department of Crop Science, Faculty of Agriculture, University of Ruhuna, Sri Lanka

Accepted: $16^{\text {th }}$ June 2016

\begin{abstract}
Possibilities of mass producing Dalbergia latifolia Roxb. (Fabaceae) trees towards clonal propagation through in vitro techniques have been evaluated. Shoot tips excised from elite trees maintained under plant house conditions were established on Mc Cowns Woody Plant medium fortified with BAP $(1.0 \mathrm{mg} / \mathrm{L})$ and IAA $(0.5 \mathrm{mg} / \mathrm{L})$. The highest proliferation rate (4.95 shoots/shoot tip) was achieved using $3.0 \mathrm{mg} / \mathrm{L} \mathrm{BAP,} 0.5 \mathrm{mg} / \mathrm{L} \mathrm{Kin}$ and $0.5 \mathrm{mg} / \mathrm{L}$ IAA. The best establishment medium for leaves is Murashige and Skoog medium fortified with $0.5 \mathrm{or} 1.0 \mathrm{mg} / \mathrm{L}$ BAP with $1.0 \mathrm{mg} / \mathrm{L} \mathrm{2,} \mathrm{4-D} \mathrm{and} 4.0 \mathrm{mg} / \mathrm{L} \mathrm{NAA}$ to initiate compact, nodular and proliferative calli. Highest rate of shoot bud differentiation (17.7 shoot buds/ $1 \mathrm{~g}$ of callus) was achieved using $5.0 \mathrm{mg} / \mathrm{L}$ BAP with $0.2,0.5 \mathrm{or} 0.6 \mathrm{mg} / \mathrm{L}$ NAA.
\end{abstract}

Key words: Differentiation, in vitro, Proliferation, Rosewood

\section{INTRODUCTION}

Dalbergia latifolia (Fabaceae) is a slow growing, predominantly a single- stemmed deciduous tree having a dome shaped crown with lush green foliage. The trees reach a height of 20$40 \mathrm{~m}$ with a girth of $1.5-2 \mathrm{~m}$. This is native to India, Indonesia and extensively planted in Kenya, Malaysia, Myanmar, Nepal, Nigeria, Philippines and Vietnam (Orwa et al., 2009). Few decades back Forest Department-Sri Lanka established few plants at Anuradhapura forest conservation area for research purposes.

Many species of Dalbergia are prized timber because of the deep purple colour of the heartwood. It is used to make premium-grade furniture, carvings, paneling, veneers and interior and exterior joinery. Secondary uses of the wood include knife handles, musical instruments, mathematical instruments and boat keels and screws (Orwa et al., 2009).

Wood is rich in aromatic oils (rosewoods sonamed because of its odor) use in cosmetics.

*Corresponding author: subasinghesiripala@yahoo.com
Tannins from the bark are used to produce medicines for the treatment of diarrhea, worms, and indigestion (Vasudeva et al., 2009).

Poor seed viability and enormous genetic variability are the major constraints for the commercial cultivation through conventional seed propagation (Orwa et al., 2009). Collection of seeds from wild sources is laborious, as the seeds ripen a few at a time. Conventional vegetative propagation by grafting and rooted cuttings is time consuming and impossible in large scale. Therefore it is worth to develop alternative mass propagation technique for rosewood. This will accelerate biodiversity conservation and superior quality plantations.

Attempts have been made since decades to develop feasible micropropagation protocol for D. latifolia in India. Lakshmi Sita and Raghava Swamy (1993), Raghava Swamy et al., 1992 and Rai and Jagadish Chandra (1989) have reported micropropagation of rosewood using shoot tips excised from mature trees and seedlings. Rao and Lakshmi 
Sita (1996) have also reported the possibilities of somatic embryogenesis from immature seeds of D. latifolia. However Muralidharan, (1997) reported that using axillary bud as explants taken from mature trees of $D$. latifolia resulted high rates of contaminations, even the buds sprouted to form shoots they were failed to elongate and no multiple shoot formation was obtained on cytokinin containing media. Leaf explants cultured on media containing auxins and cytokinins gave rise to profuse callusing however no morphogenesis was obtained on a wide range of media. Therefore the current study was planned to develop feasible micropropagation protocol with reference to research carried out up to certain extent in the world while addressing the encountered specific draw backs.

\section{MATERIALS AND METHODS}

All the experiments were carried out at the Tissue Culture Laboratory, Department of Crop Science, Faculty of Agriculture, University of Ruhuna, Mapalana, Kamburupitiya, Sri Lanka in 2012. The culture media were adjusted to $\mathrm{pH}$ $5.8,0.8 \%(\mathrm{w} / \mathrm{v})$ agar was added before sterilization at $1.06 \mathrm{~kg} / \mathrm{cm}^{2}$ steam pressure for $20 \mathrm{~min}$. The cultures were incubated at a temperature of $25 \pm 2{ }^{\circ} \mathrm{C}$ under $16 \mathrm{~h}$ daily illuminations with white fluorescent light (2,500 lux) throughout the study.

\section{Maintenance of mother plants}

Mother plants established from rooted cuttings were maintained under plant house conditions free from pests and diseases. Plants were watered as necessary avoiding overhead watering. Thiophanate methyl 70\% WP, $1 \mathrm{~g} / 1$ was sprayed $24 \mathrm{~h}$ before collecting the explants for culturing to prevent fungal infections.

\section{Surface sterilization of explants}

Leaves and shoot tips $(2 \mathrm{~cm})$ were used as explants. They were dipped in $0.1 \%$ systemic fungicide (Topsin) for $1 \mathrm{~h}$ then washed thoroughly using running tap water for 15 minutes.
Then they were surface sterilized using $10 \%$, $15 \%$ and $20 \%$ clorox $(5.25 \% \mathrm{NaOCl})$ for 10 , 15 and 20 minutes followed by $70 \%$ ethanol for 2 minutes. Explants were kept after excising to proper size in sterilized distilled water up to $15 \mathrm{~min}$. After exposing to each chemical explants were thoroughly washed thrice using sterilized distilled water.

\section{In vitro establishment of shoot tips and mul- tiplication}

Shoot tips were cultured on MS (Murashige and Skoog, 1962) and WPM (Lloyd and McCown, 1980) basal media. To evaluate the effect of plant growth regulators and coconut water on growth performances of explants 1.0 $\mathrm{mg} / \mathrm{L}$ 6-Benzyle Amino Purine (BAP) alone, $1.0 \mathrm{mg} / \mathrm{L}$ BAP with $0.05 \mathrm{mg} / \mathrm{L}$ of Napthaline Acetic Acid (NAA), $1.0 \mathrm{mg} / \mathrm{L}$ BAP with 0.5 $\mathrm{mg} / \mathrm{L}$ of Indol Acetic Acid (IAA) and coconut water $(100-250 \mathrm{ml} / \mathrm{L})$ were incorporated to the MS and WPM media as separate treatments. LGlutamine $(750-1000 \mathrm{mg} / \mathrm{L})$ was added to MS and WPM media to evaluate its effect on controlling leaf shedding which identified as a problem occurred after 3-4 weeks from culture establishment of previous experiment. After 4 weeks from culture establishment non contaminated shoots were transferred to WPM medium fortified with $1.0,2.0$ and $3.0 \mathrm{mg} / \mathrm{L}$ of BAP, $0.0,0.5$ and $1.0 \mathrm{mg} / \mathrm{L}$ Kin and $0.0,0.5 \mathrm{mg} / \mathrm{L}$ of IAA or $0.0,0.05 \mathrm{mg} / \mathrm{L}$ NAA to evaluate the effect of plant growth regulators towards in vitro shoot multiplication. The observations were taken up to 8 weeks.

\section{Callus induction, proliferation and regen- eration of shoots from leaf ex-plant}

Leaves were cultured on MS and WPM basal media separately to initiate calli. Sterilized leaves were excised into $1 \mathrm{~cm} \mathrm{x} 1 \mathrm{~cm}$ squares and placed either abaxially or adaxially on the medium fortified with 0.5 and $1.0 \mathrm{mg} / \mathrm{L}$ of BAP and $0.5,1.0$ and $1.5 \mathrm{mg} / \mathrm{L}$ of 2 , 4Dichlorophenoxy Acetic Acid (2, 4-D) and 2.0, 4.0 and $6.0 \mathrm{mg} / \mathrm{L} \mathrm{NAA}$ to evaluate the effect of culture medium, plant growth regulators and 
physical environmental such as temperature and humidity towards in vitro callus formation. Four weeks after callus initiation $1 \mathrm{~g}$ weight of callus masses were transferred to regeneration media fortified with 4.0, 5.0 and $6.0 \mathrm{mg} / \mathrm{L}$ BAP and $0.2,0.3,0.4,0.5$ and 0.6 $\mathrm{mg} / \mathrm{L}$ NAA in MS medium. Regeneration ability of those callus masses into shoots were evaluated up to 12 weeks.

\section{Experimental design and statistical analy- sis}

All the experiments were designed according to the Factorial Completely Randomized Design (CRD) with 20 replicates. Experiments were repeated three times. Contamination percentages, number of new shoot buds appeared and amount, texture and colour of the callus tissues were collected weekly. Non parametric data were analyzed by Kruskalwallis test and parametric data were analyzed by ANOVA test using SAS statistical software. Means were separated by using Duncan's Multiple Range Test.

\section{RESULTS AND DISCUSSION}

\section{Surface sterilization of leaves and axillary shoot buds}

For surface sterilization of leaves two factor interactions were not significant at $\mathrm{P} \leq 0.05$ probability level. The $20 \%$ clorox concentration showed highest non contamination rate

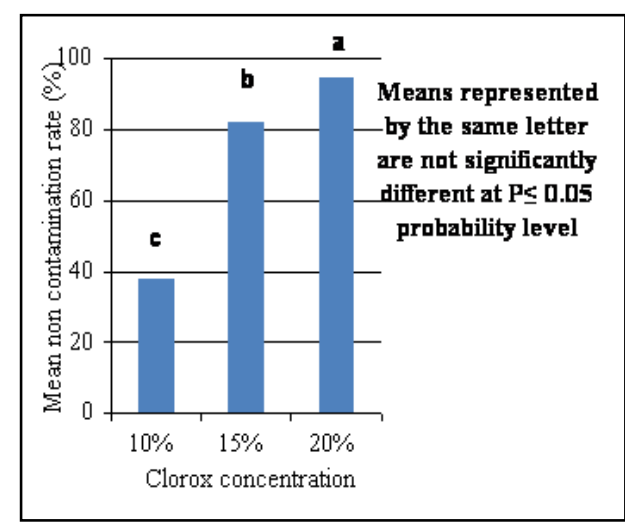

Figure 1: Effect of clorox concentration on mean non contamination rates of leaves compared to $10 \%$ clorox at $\mathrm{P} \leq 0.05$ significant level (Figure 01) and 10, 15 and 20 minutes exposure times did not significantly different $(\mathrm{P} \leq 0.05)$ to each other. However after exposing to $20 \%$ clorox and for 20 minutes time, leaves were not survived due to the browning of leaf tissues.

For surface sterilization of shoots two factor interactions were not significant at $\mathrm{p} \leq 0.05$ probability level. Among the treatments tested $15-20 \%$ Clorox solution and 20 minute exposure time found to be the best for surface sterilization (Table 01).

Table 1: Effect of Clorox concentration and exposure time on mean non contamination rates of shoots

\begin{tabular}{lll}
\hline Treatment & & \multicolumn{2}{l}{$\begin{array}{l}\text { Mean non } \\
\text { contamination } \\
\text { rate }(\%)\end{array}$} \\
\hline \multirow{2}{*}{$\begin{array}{l}\text { Clorox } \\
\text { concentration }\end{array}$} & $10 \%$ & $21.50^{\mathrm{b}} \pm 0.00$ \\
\cline { 2 - 3 } & $15 \%$ & $73.82^{\mathrm{a}} \pm 0.07$ \\
\cline { 2 - 3 } $\begin{array}{l}\text { Exposure } \\
\text { time }\end{array}$ & $10 \%$ & $91.07^{\mathrm{a}} \pm 0.17$ \\
\cline { 2 - 3 } & $15 \mathrm{~min}$ & $41.61^{\mathrm{c}} \pm 0.00$ \\
\cline { 2 - 3 } & $20 \mathrm{~min}$ & $89.12^{\mathrm{b}} \pm 0.11$ \\
\hline
\end{tabular}

Means represented by the same letter case are not significantly different at $\mathrm{P} \leq 0.05$ probability level

However, after exposing to $20 \%$ clorox and for 20 minutes time shoots were turned into brown colour. Even though these shoots were not contaminated, they did not show any growth increment during 4 weeks of observation period.

\section{In vitro establishment and multiplication of shoots from leaf ex-plants}

Explants established on WPM medium fortified with $1.0 \mathrm{mg} / \mathrm{L} \mathrm{BAP}$ and $0.5 \mathrm{mg} / \mathrm{L} \mathrm{IAA}$ produced highest number of buds (5.95 buds/ explant) compared to the $1.0 \mathrm{mg} / \mathrm{L}$ BAP with 
$0.05 \mathrm{mg} / \mathrm{L}$ NAA (4.95 buds/ explant) at $\mathrm{P} \leq$ 0.05 probability level (Table 02). However incorporation of coconut water into culture medium was not effective in increasing growth performances of explants. Shedding of bract like structures was a serious problem arouse, after 3-4 weeks from culture establishment, which was failed to control by incorporating glutamine into the culture medium.

Table 02: Number of new buds produced by explants under different media compositions

\begin{tabular}{|c|c|}
\hline $\begin{array}{c}\text { Medium } \\
\text { CV 15.91 LSD } 0.25\end{array}$ & $\begin{array}{c}\text { Number } \\
\text { of new } \\
\text { buds }\end{array}$ \\
\hline MS & $0.00^{\mathrm{g}}$ \\
\hline $\mathrm{MS}+\mathrm{BAP}(1.0 \mathrm{mg} / \mathrm{L})$ & $1.95^{\mathrm{e}}$ \\
\hline $\begin{array}{l}\mathrm{MS}+\mathrm{BAP}(1.0 \mathrm{mg} / \mathrm{L})+\mathrm{NAA} \\
(0.05 \mathrm{mg} / \mathrm{L})\end{array}$ & $2.95^{\mathrm{d}}$ \\
\hline $\begin{array}{l}\text { MS+ BAP }(1.0 \mathrm{mg} / \mathrm{L})+\mathrm{IAA} \\
(0.5 \mathrm{mg} / \mathrm{L})\end{array}$ & $3.05^{\mathrm{d}}$ \\
\hline $\begin{array}{l}\mathrm{MS}+\text { Coconut water }(100 \\
\mathrm{ml} / \mathrm{L})\end{array}$ & $0.00^{\mathrm{g}}$ \\
\hline $\begin{array}{l}\text { MS+ Coconut water }(250 \\
\mathrm{ml} / \mathrm{L})\end{array}$ & $0.00^{\mathrm{g}}$ \\
\hline MS+ Glutmine $(750 \mathrm{mg} / \mathrm{L})$ & $0.00^{\mathrm{g}}$ \\
\hline MS+ Glutmine $(1 \mathrm{~g} / \mathrm{L})$ & $0.00^{\mathrm{g}}$ \\
\hline WPM & $1.00^{\mathrm{f}}$ \\
\hline WPM+ BAP (1.0 mg/L) & $3.95^{\mathrm{c}}$ \\
\hline $\begin{array}{l}\text { WPM+ BAP }(1.0 \mathrm{mg} / \mathrm{L})+ \\
\text { NAA }(0.05 \mathrm{mg} / \mathrm{L})\end{array}$ & $4.95^{\mathrm{b}}$ \\
\hline $\begin{array}{l}\text { MS+ BAP }(1.0 \mathrm{mg} / \mathrm{L})+\text { IAA } \\
(0.5 \mathrm{mg} / \mathrm{L})\end{array}$ & $5.95^{\mathrm{a}}$ \\
\hline $\begin{array}{l}\text { WPM+ Coconut water }(100 \\
\mathrm{ml} / \mathrm{L})\end{array}$ & $0.00^{\mathrm{g}}$ \\
\hline $\begin{array}{l}\text { WPM+ Coconut water }(250 \\
\mathrm{ml} / \mathrm{L})\end{array}$ & $0.00^{\mathrm{g}}$ \\
\hline WPM+ Glutmine $(750 \mathrm{mg} / \mathrm{L})$ & $0.00^{\mathrm{g}}$ \\
\hline WPM+ Glutmine $(1 \mathrm{~g} / \mathrm{L})$ & $0.00^{\mathrm{g}}$ \\
\hline
\end{tabular}

Means represented by the same letter are not significantly different at $\mathrm{P} \leq 0.05$ probability level

During the multiplication phase, highest number of shoots (4.95 shoots/ explant) was resulted in WPM medium fortified with $3.0 \mathrm{mg} /$ L BAP, $1.0 \mathrm{mg} / \mathrm{L} \mathrm{Kin}$ and $0.5 \mathrm{mg} / \mathrm{L}$ IAA (Table 03). However, it was difficult to main- tain those shoots for a longer period of time as they started leaf shedding and subsequent die back of shoots.

Table 03: Number of new shoots per explant as affected by plant growth regulator combination

\begin{tabular}{|c|c|c|c|}
\hline \multicolumn{3}{|c|}{$\begin{array}{l}\text { Plant growth } \\
\text { regulator } \\
\text { combination }(\mathrm{mg} / \mathrm{L})\end{array}$} & \multirow{2}{*}{$\begin{array}{l}\text { Number of } \\
\text { new shoots/ } \\
\text { explant } \\
\text { CV } 13.14\end{array}$} \\
\hline BAP & Kin & IAA & \\
\hline 1 & 0 & 0 & $0.75 \mathrm{~d} \pm 0.44$ \\
\hline 1 & 0 & 0.5 & $1.70 \mathrm{c} \pm 1.66$ \\
\hline 1 & 0.5 & 0 & $3.15 \mathrm{~b} \pm 1.66$ \\
\hline 1 & 0.5 & 0.5 & $2.95 \mathrm{~b} \pm 1.66$ \\
\hline 1 & 1 & 0 & $2.50 b c \pm 0.51$ \\
\hline 1 & 1 & 0.5 & $2.50 b c \pm 0.51$ \\
\hline 2 & 0 & 0 & $0.65 \mathrm{~d} \pm 0.48$ \\
\hline 2 & 0 & 0.5 & $1.40 \mathrm{c} \pm 0.75$ \\
\hline 2 & 0.5 & 0 & $2.50 b c \pm 0.51$ \\
\hline 2 & 0.5 & 0.5 & $1.60 \mathrm{c} \pm 0.50$ \\
\hline 2 & 1 & 0 & $1.70 \mathrm{c} \pm 0.47$ \\
\hline 2 & 1 & 0.5 & $1.60 \mathrm{c} \pm 0.50$ \\
\hline 3 & 0 & 0 & $1.00 \mathrm{c} \pm 0.00$ \\
\hline 3 & 0 & 0.5 & $3.95 \mathrm{~b} \pm 0.82$ \\
\hline 3 & 0.5 & 0 & $4.00 \mathrm{~b} \pm 0.79$ \\
\hline 3 & 0.5 & 0.5 & $4.95 \mathrm{a} \pm 0.51$ \\
\hline 3 & 1 & 0 & $2.50 b c \pm 0.51$ \\
\hline 3 & 1 & 0.5 & $2.50 b c \pm 0.51$ \\
\hline
\end{tabular}

Means represented by the same letter are not significantly different at $\mathrm{P} \leq 0.05$ probability level

\section{Callus induction, proliferation and regen- eration of shoots}

During initial studies it was observed that MS medium produced more calli than WPM medium. However, even with some auxins the calli produced were in whitish colour, loose, 
watery and fragile in texture with less regeneration potential. Therefore, MS medium with series of Plant growth regulators were allocated (Table 04) to improve the quality and quantity of callus.

Table 04: Plant growth regulator combinations used for callus induction and multiplication

\begin{tabular}{|c|c|c|c|}
\hline \multicolumn{3}{|c|}{$\begin{array}{l}\text { Plant growth regulator } \\
\text { combination }\end{array}$} & \multirow[b]{2}{*}{$\begin{array}{l}\text { Callus } \\
\text { amount }\end{array}$} \\
\hline $\begin{array}{l}\text { BAP } \\
(\mathrm{mg} / \mathrm{L})\end{array}$ & $\begin{array}{l}2,4- \\
\mathrm{D} \\
(\mathrm{mg} / \\
\mathrm{L})\end{array}$ & $\begin{array}{l}\text { NAA } \\
(\mathrm{mg} / \\
\mathrm{L})\end{array}$ & \\
\hline 0.5 & 0.5 & 2 & + \\
\hline 0.5 & 0.5 & 4 & + \\
\hline 0.5 & 0.5 & 6 & + \\
\hline 0.5 & 1 & 2 & ++ \\
\hline 0.5 & 1 & 4 & +++++ \\
\hline 0.5 & 1 & 6 & +++ \\
\hline 0.5 & 1.5 & 2 & +++ \\
\hline 0.5 & 1.5 & 4 & +++ \\
\hline 0.5 & 1.5 & 6 & +++ \\
\hline 1 & 0.5 & 2 & ++ \\
\hline 1 & 0.5 & 4 & +++ \\
\hline 1 & 0.5 & 6 & +++ \\
\hline 1 & 1 & 2 & +++ \\
\hline 1 & 1 & 4 & +++++ \\
\hline 1 & 1 & 6 & ++++ \\
\hline 1 & 1.5 & 2 & ++++ \\
\hline 1 & 1.5 & 4 & ++++ \\
\hline 1 & 1.5 & 6 & ++++ \\
\hline
\end{tabular}

Leaf swelling and curling was observed a week after culture initiation. After 2 weeks, leaf tissues cultured as their lower epidermis touching the medium produced callus from cutting edges and mid ribs. Leaf segments cultured inverted direction produced less callus and rolled upward. The texture, colour and the amount of callus were varying ac- cording to the plant growth regulators presence in the media (Table 04).

Highest amount of calli were resulted with 0.5 $\mathrm{mg} / \mathrm{L}$ BAP, $1.0 \mathrm{mg} / \mathrm{L} 2$, 4-D and $4.0 \mathrm{mg} / \mathrm{L}$ NAA and $1.0 \mathrm{mg} / \mathrm{L} \mathrm{BAP,} 1.0 \mathrm{mg} / \mathrm{L} 2,4-\mathrm{D}$ and $4.0 \mathrm{mg} / \mathrm{L}$ NAA during 4 weeks of observation period (Table 04). They were compact, hard and proliferative in texture and chlorophyllous in colour.

Proliferated callus tissues were transferred to MS media containing higher concentrations of BAP combined with low levels of NAA to facilitate regeneration of shoots. Highest number of shoot buds was regenerated in media containing $5.0 \mathrm{mg} / \mathrm{L}$ BAP either with $0.2,0.4$ or $0.6 \mathrm{mg} / \mathrm{L}$ NAA (Table 05 ).

Table 05: Number of shoot buds as affected by plant growth regulator combination

\begin{tabular}{|c|c|c|}
\hline \multicolumn{2}{|c|}{$\begin{array}{l}\text { Plant growth } \\
\text { regulator } \\
\text { combination }(\mathrm{mg} / \mathrm{L})\end{array}$} & \multirow[t]{2}{*}{$\begin{array}{l}\text { Number of shoot } \\
\text { buds/ } 1 \mathrm{~g} \text { of callus } \\
\text { CV } 9.02\end{array}$} \\
\hline$\overline{\mathrm{BAP}}$ & NAA & \\
\hline 4 & 0.2 & $3.95^{\mathrm{f}} \pm 0.82$ \\
\hline 4 & 0.3 & $2.95^{\mathrm{g}} \pm 0.82$ \\
\hline 4 & 0.4 & $1.95^{\mathrm{g}} \pm 0.82$ \\
\hline 4 & 0.5 & $1.50^{g} \pm 0.51$ \\
\hline 4 & 0.6 & $1.50^{\mathrm{g}} \pm 2.23$ \\
\hline 5 & 0.2 & $17.70^{\mathrm{a}} \pm 1.78$ \\
\hline 5 & 0.3 & $15.95^{\mathrm{b}} \pm 0.82$ \\
\hline 5 & 0.4 & $15.50^{\mathrm{b}} \pm 0.51$ \\
\hline 5 & 0.5 & $18.50^{\mathrm{a}} \pm 0.51$ \\
\hline 5 & 0.6 & $17.00^{\mathrm{a}} \pm 0.00$ \\
\hline 6 & 0.2 & $9.95^{\mathrm{c}} \pm 0.82$ \\
\hline 6 & 0.3 & $8.95^{c} \pm 0.82$ \\
\hline 6 & 0.4 & $7.50^{\mathrm{d}} \pm 0.51$ \\
\hline 6 & 0.5 & $5.50^{\mathrm{e}} \pm 0.51$ \\
\hline 6 & 0.6 & $2.50^{g} \pm 0.51$ \\
\hline
\end{tabular}

Means represented by the same letter are not significantly different at $\mathrm{P} \leq 0.05$ probability level 


\section{Surface sterilization of leaves and shoots}

It was recorded that $0.1-1.0 \%$ of $\mathrm{HgCl}_{2}(\mathrm{w} / \mathrm{v})$ has been used for 5-10 minutes for the surface sterilization of shoot tips and nodal explants of rosewood (Muralidharan, 1997). Another report cited that the leaves of D. latifolia were successfully surface sterilized by passing them through a series of treatments as:

(i) 5-10 min in running tap water, (ii) $10-15$ min of $5 \%(\mathrm{v} / \mathrm{v})$ Teepol solution, (iii) $15-20$ min in running tap water, (iv) 5-8 rinses in double distilled water, (v) $8-12 \mathrm{~min}$ in $0.1 \%$ mercuric chloride and (vi) 4-6 rinses in sterile distilled water (Lakshmi Sita and Raghava Swamy, 1993).

During this study tender shoots and leaves of D. latifolia were successfully surface sterilized by dipping them in $0.1 \%$ Topsin solution for $1 \mathrm{~h}$ as the initial step of surface sterilization then by keeping 15 minutes under running tap water and then using $15 \%$ Clorox for 15 minutes followed by $70 \%$ ethanol for 2 minutes.

However, during the current study due to the browning of tissues, it was difficult to dip explants more than 15 minutes even under running tap water and it was not possible to wash explants several times using sterilized distilled water (possible up to two washes).

When considering the toxicity of $\mathrm{HgCl}_{2}$ as a heavy metal, proper disposal system is essential and it is a banded chemical in Sri Lanka today. Therefore, the developed surface sterilization procedure en-counts high value while practicing this micropropagation protocol in Sri Lanka.

\section{In vitro establishment and multiplication of shoots}

It was reported that browning of explants and exudation of phenolic compounds into the culture media can be minimized by keeping the explants in running water, in solutions of $0.25 \%(\mathrm{w} / \mathrm{v})$ activated harcoal or $0.5 \%$ Polyvinyl pyrrolidone or $150 \mathrm{mg} / \mathrm{L}$ citric acid for 1 h. or for $30 \mathrm{~min}$ after which the surface sterilization was carried out (Muralidharan, 1997). Incorporation of Polyvinyl pyrrolidone, ascorbic acid and activated charcoal to the culture media to prevent browning of the explants was recorded as well (Lakshmi Sita and Raghava Swamy, 1993). However during the current study we didn't observed browning of explants or accumulation of phenolic exudates in culture media throughout the study, this may be due to the usage of tender shoots as explants and the improved surface sterilization procedure followed.

Cultured shoots produced higher number of buds on WPM medium compared to MS medium. Incorporation of plant growth regulators into the culture medium was more effective to induce bud formation where a combination of BAP and IAA performed well compared to BAP alone or with NAA. However coconut water even it is recognized as a rich source of vitamins, amino acids and some cytokinins (i.e: Kin) (Yong et al., 2009), not facilitate bud initiation of $D$. latifolia shoots. Therefore it was suggested that BAP is much better than Kin towards the initiation of buds.

However, a contradictory result was reported (Muralidharan, 1997) that was 20\% of shoot tips and axillary buds used as explants were sprouted after two weeks on cytokinin containing medium where the concentration and type of the cytokinin has no effect on the initial sprouting response. The author further mentioned that the shoot tips responded better than axillary buds in developing a sprout and shoots elongated to about $8-10 \mathrm{~mm}$. in 4 weeks on different concentrations of cytokinins without producing multiple shoots. The shoots had only bract-like structures and these often fell off before 4 weeks. The unelongated shoots remained live for another 4 weeks if sub cultured then they were turned brown. 
During our study as well we observed the initiated buds turned into bract-like structures and fallen off after 3-4 weeks from culture initiation. This could not be controlled by incorporating glutamine $(750-1000 \mathrm{mg} / \mathrm{L})$ alone into the culture media. However, it was reported that the possibility of glutamine in a modified WPM medium to control this problem up to certain extent (Raghava Swamy et al., 1992; Lakshmi Sita and Raghava Swamy, 1993). Therefore, further experiments are needed to identify a modified WPM medium to address this problem. However, during this study sub culturing of shoots 4 weeks after culture initiation into WPM media fortified with higher concentration $(3.0 \mathrm{mg} / \mathrm{L})$ of BAP, $0.5 \mathrm{mg} / \mathrm{L}$ Kin and $0.5 \mathrm{mg} / \mathrm{L}$ IAA produced highest number of new shoots. These results (Table 03) highlight the importance of 2 cytokinins in combination with IAA to accelerate shoot proliferation. To overcome leaf shedding and dye back of shoots it is important to make modifications in WPM medium as well.

\section{Callus induction, proliferation and regen- eration of shoots}

MS medium supplemented with auxins- 0.5 , 1.0 and $1.5 \mathrm{mg} / \mathrm{L} 2,4-\mathrm{D}$ alone or with combination of $2.0,4.0$ and $6.0 \mathrm{mg} / \mathrm{L}$ NAA produced yellowish, loose, friable callus (Figure 02) which was not suitable for organogenesis.

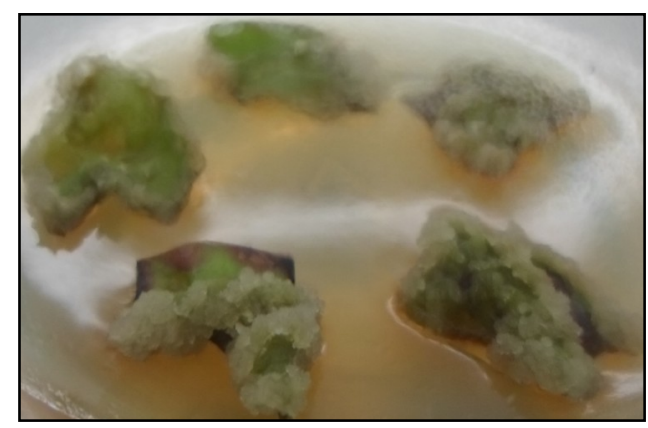

Figure 02: Yellowish, loose, friable callus from leaf ex plant which was not suitable for organogenesis

The best callus growth from leaf tissues was obtained on MS medium supplemented either by 0.5 or $1.0 \mathrm{mg} / \mathrm{L}$ of BAP combined with 1.0 $\mathrm{mg} / \mathrm{L} 2,4-\mathrm{D}$ and $4.0 \mathrm{mg} / \mathrm{L}$ NAA. This highly compact, hard, nodular, fast proliferating and chlorophyllous callus (Figure 03) was transferred to regeneration media, 4 weeks after culture initiation.

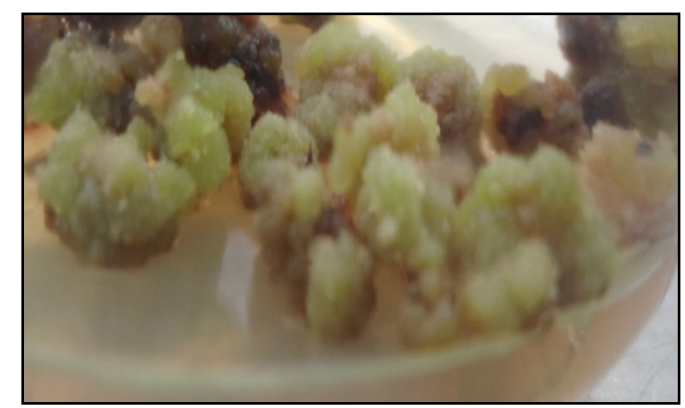

Figure 03: Highly compact, hard, nodular, fast proliferating and chlorophyllous callus produced from leaf ex-plant

For shoot multiplication, it is discussed the necessity of higher concentration of $(3.0 \mathrm{mg} /$ L) BAP. Therefore in regeneration media as well it is beneficial to increase the levels of BAP. To maintain Cytokinin: auxin ratio in a higher value which facilitates shooting, reduced levels of NAA were allocated (Table 05). Shoot bud differentiation started after 5-6 sub culturing in 4 week intervals. A maximum of 17-19 shoot bud differentiation was observed on media supplemented with $5.0 \mathrm{mg} / \mathrm{L}$ BAP and $0.2,0.5$ and $0.6 \mathrm{mg} / \mathrm{L}$ NAA after the $8^{\text {th }}$ sub culture. A steady increase in the BAP concentration $(6.0 \mathrm{mg} / \mathrm{L})$ with all the tested NAA concentrations decreased the shoot bud differentiation. Further experiments are needed to evaluate the effect of IAA with BAP on callus formation and regeneration of shoots. Experiments are still continuing to optimize shoot and root differentiation protocols.

\section{CONCLUSION}

Shoot tips and leaves of Rosewood can be surface sterilized by dipping explants for $1 \mathrm{~h}$ in $0.1 \%$ solution of systemic fungicide (i.e. Thiophanate methyl $70 \% \mathrm{WP}) ; 15$ minutes in $15 \%$ clorox $(5.25 \% \mathrm{NaOCl})$ and 2 minutes in $70 \%$ 
ethanol. After each exposing to chemicals the explants have to be washed twice using sterilized distilled water.

The best establishment medium for shoot tips is found to be Mc Cowns Woody Plant medium fortified with BAP $(1.0 \mathrm{mg} / \mathrm{L})$ and IAA $(0.5 \mathrm{mg} / \mathrm{L})$. The highest proliferation rate (4.95 shoots/ explant) can be achieved using $3.0 \mathrm{mg} / \mathrm{L} \mathrm{BAP}, 0.5 \mathrm{mg} / \mathrm{L} \mathrm{Kin}$ and $0.5 \mathrm{mg} / \mathrm{L}$ IAA. The best establishment medium for leaves is Murashige and Skoog medium fortified with 0.5 or $1.0 \mathrm{mg} / \mathrm{L}$ BAP with $1.0 \mathrm{mg} / \mathrm{L}$ 2, 4-D and $4.0 \mathrm{mg} / \mathrm{L}$ NAA. Highest rate of shoot bud differentiation (17.7 shoot buds/ $1 \mathrm{~g}$ of callus) can be achieved using $5.0 \mathrm{mg} / \mathrm{L}$ BAP with $0.2,0.5$ or $0.6 \mathrm{mg} / \mathrm{L}$ NAA.

\section{ACKNOWLEDGMENT}

The authors wish to thank the University of Ruhuna for funding the project under the Transforming the University of Ruhuna to International Level (grant No. RUV/DVC/ PRO 152) and the Forest Department, Sri Lanka for the providing elite planting materials.

\section{REFERENCE}

Lakshmi Sita G and Raghava Swamy BV 1993 Regeneration of plantlets from leaf disc cultures of rosewood: control of leaf abscission and shoot tip necrosis. Plant Science, 88: 107-112.

Lloyd G and McCown BH 1981 Commercially feasible micropropagation of mountain laurel, Kalmia latifolia, by use of shoot tip culture. Proc. Int. Plant Prop. Soc., 30: 421-427.

Muralidharan EM 1997 Micropropagtion of teak, rosewood and sandal. KFRI Research Report 119 Kerala Forest Research Institute Peechi, Thrissur, India.

Murashige T and Skoog F 1962 A revised medium for rapid growth and bioassay with tobacco tissue cultures. Physiol. Plant, 15: 473-497.

Orwa C, Mutua A, Kindt R, Jamnadass R and Simons A 2009 Agroforestry Database: a tree reference and selection guideVersion-4, World Agroforestry Center, Kenya.

Raghava Swamy BV, Himabindu K and Lakshmi Sita G 1992 In vitro micropropagation of elite Rosewood (Dalbergia latifolia Roxb.) Plant Cell Reports 11: 126131.

Rai VR and Jagadish Chandra KS 1989 Micropropagation of Indian Rosewood by tissue culture. Ann. Bot.. 64: 4346 . a ob.ox fordjournals.org/ content $/ 64 / 1 / 43$

Rao MM and Lakshmi Sita G 1996 Direct somatic embroygenesis from immature embryos of rosewood (Dalbergia latifolia Roxb.) Plant Cell Reports 15: 355-359.

Vasudeva N, Vats M, Sharma S K, Sardana S. Chemistry and biological activities of the genus Dalbergia - A review. Phcog Rev [serial online] 2009 [cited 2015 Jul 12];3:307-19. Available from: http:// w w w.phcogrev.com/text.as p ? 2009/3/6/307/59529

Yong JWH, Ge Liya, Fei Ng, Yan Tan and Swee Ngin 2009 The chemical composition and biological properties of coconut (Cocos nucifera L.) water. Marikar, F. M. M. T. // Micologia Aplicada International, 21 Issue 2: 63. 